\title{
THE LANGUAGES OF PEACE DURING THE FRENCH RELIGIOUS WARS
}

The four-hundredth anniversary of the Edict of Nantes stimulated a steady stream of conferences and publications, not only focusing on the establishment of peace in France in 1598, but also its significance throughout the religious wars and beyond. ${ }^{1}$ A variety of perspectives emerged on the construction and application of peace in a confessionally-divided realm, but no systematic examination of the complexity of contemporary reactions which this essay seeks to address. ${ }^{2}$ A decade ago, Denis Crouzet recreated a neoplatonic vision of the Valois monarchy's dream of reestablishing harmony and unity in the kingdom through an enduring peace. ${ }^{3}$ Recent research has reinforced the impression that, in the face of civil strife, French kings sought reconciliation as the highest goal. ${ }^{4}$ Yet their subjects were far more circumspect about the chances for an enduring settlement. The languages of peace erected a sometimes insuperable barrier of mutual misunderstanding between the faiths that no degree of royal diplomacy could break down. The most prominent opinions were expressed in printed texts by royal officials, poets, and preachers, but it is also possible to hear the sometimes discordant voices contained in various manuscript sources which record the views of local communities on the merits and drawbacks of pacification.

Peace was many-faceted and complicated further by confessional schism: who did it benefit, and at what cost, and should toleration of another faith even be contemplated let alone embraced? What impact did the practical experience of religious coexistence and interconfessional violence have on the desirability or possibility of reconciling division? Concord - implying not only religious but also political and national unity - was an ideal which both faiths could uphold, whereas toleration could only ever be a temporary, and contested, solution. ${ }^{5}$ The words most 
frequently used on all sides, peace ('paix') and repose ('repos'), upheld a universal quest for an end to civil strife. Nevertheless, whilst Huguenot and Catholic could agree that religious disunity was detrimental to the well-being of the kingdom, they held opposing views on which religious position should prevail and the best means by which to secure peace. Yet opinion was not just divided along confessional lines; political imperatives, philosophical positions, and local conditions all came into play in the arguments deployed. Some asserted that, however unpalatable conciliation between the faiths might be, its consumption was necessary if the kingdom were to (avoid or) break the destructive cycle of civil war. Others claimed that the very existence of two faiths perpetuated conflict. The prospect of peace was contentious at a time of entrenched division. ${ }^{6}$ There was little dialogue but rather a clamour of competing discourses, and the extent to which they were heard and acknowledged by the crown or the people varied with each phase of the wars. ${ }^{7}$

\section{Traditions of Peace}

The quest for the establishment of a lasting peace in sixteenth-century France arose from a unique set of circumstances peculiar to the period. Yet the linguistic repertoire from which those who advocated peace were able to draw was well established, containing classical, biblical and humanist models - from Cicero and St Augustine to Erasmus - as well as the rhetorical conventions of medieval royal power. ${ }^{8}$ Nor was this the first time that the realm was faced by internal divisions which prompted authors to explore the virtues of peace and unity. ${ }^{9}$ Just prior to and throughout the wars the discussion of how best to secure peace was articulated in Renaissance poetry and abstract political treatises, as well as in royal correspondence and proclamations which sought a practical solution to the troubles. The languages of peace were reiterated in the deliberations of town councils and the directives of royal officials, in 
judicial and municipal assemblies, and in petitions and remonstrances to the crown from both confessions. They were acted out in the traditional gestures of affection and reconciliation - the kiss of peace, the embrace between former enemies, the oath of mutual assistance - all of which played a part in contemporary public rituals. ${ }^{10}$ Peace between warring states was often sealed by a marriage; that between the Huguenot leader, Henry of Navarre, and the king’s sister, Marguérite, in 1572 upheld this tradition. ${ }^{11}$ Dining or hunting together and the exchange of gifts reinforced verbal and written assurances. ${ }^{12}$ In art, too, the virtues and benefits of peace were joyously celebrated. The French crown's imperial aspirations were reflected in the iconography which projected successive monarchs as universal pacifiers bringing eternal peace, primarily to their country but ultimately to the whole of Christendom. ${ }^{13}$ It was understood that the king embraced peace through a combination of divine guidance and his own volition, that true peace was inspired by God in the heart of the prince. ${ }^{14}$ In most circumstances, the desirability of peace was self-evident. However, whilst a diplomatic treaty with England in 1564 was described as a 'good, firm, sincere, stable and perpetual peace, friendship and reconciliation', the prospects for internal accord were more uncertain. ${ }^{15}$ Civil strife and confessional division in sixteenth-century France led to a particular reading and understanding of the obligation of the monarch to restore peace to the kingdom. The 'Most Christian' king was expected to uphold the divine preference for peace between his subjects, but also to defend the principle of religious unity. The royal solution to this sensitive dilemma was a temporary peace pending a resolution of confessional difference. This strategy was first attempted in the Edict of January 1562; within three months the country was at war. The later edicts of pacification which strove to restore peace, and the policy they represented, would remain controversial. 
Those who supported a policy of confessional conciliation couched their arguments in terms of monarchical duty. In this, they echoed the views of Jean Gerson who, in 1408 in a speech to the parlement of Paris, cited internal peace as the 'end and foundation of good lordship and of sound royal rule', and emphasised the importance of domestic unity. ${ }^{16}$ Classical and biblical precedents were sought; comparison with Augustus and Kings David and Solomon inevitably followed. ${ }^{17}$ In 1572, court poet, Jean-Antoine de Baïf, exhorted Christian rulers to uphold peace and reject war, for 'true glory resides in preserving virtue and justice'. ${ }^{18}$ Similar sentiments were expressed following Henry IV's conversion in 1593 that, under a faithful prince, justice and peace will return. ${ }^{19}$ It became a commonplace for theorists to argue that the king's traditional curative powers, themselves associated with royal clemency, could be extended to the healing of divisions within the kingdom. ${ }^{20}$ Adopting this metaphor, Charles IX urged in 1571 that 'by the benefit of peace, I can heal ... the wounds made by ... the troubles'. ${ }^{21}$ The description of war as a plague, infection or illness which only peace could cure was as ubiquitous as the inseparability of the monarch and the resolution of conflict. ${ }^{22}$ The powerful religious element in the royal obligation to maintain the peace enabled the king to present his peace as for the good of all. ${ }^{23}$ Henry IV urged registration of the Edict of Nantes, 'for the good of the peace', adding that 'the state's peace is the church's peace', thereby asserting royal supremacy in such matters. ${ }^{24}$

Royal rhetoric drew on a 'vigorous and durable tradition of extra-judicial settlement' in which the ruler acted as arbitrator in disputes between his subjects. ${ }^{25}$ Other individuals, such as members of the nobility, and institutions, such as the parlements, traditionally assumed this function in the localities. ${ }^{26}$ In seeking to establish a nationwide royal peace, embodied in legislation and enforced by men of 
law, the monarchy was asserting a long-held aspiration. ${ }^{27}$ All parties could agree that peace was an ideal to be striven for; especially prominent were notions of a universal or divinely-bestowed peace. The misfortunes of conflict were contrasted with the benefits of a pacified realm; as the crown declared in 1563, 'after a long and most unfortunate war that has brought us great calamity, ruin and desolation, and an infinite number of terrible afflictions ... God has consoled us with a universal peace' ${ }^{28}$ In a speech to the Paris parlement in 1571, Charles IX referred to the recent troubles 'appeased by divine providence'. ${ }^{29}$ For the Huguenot commander, François de La Noue the desire for peace ought to be universal, and whatever form it took should be accepted as God's will. ${ }^{30}$

Through much of the wars the monarchy believed that its edicts of pacification held out the best hope for the establishment and maintenance of a lasting peace. By its edicts, royal policy upheld the view of Chancellor L'Hospital that it was, 'better to pacify things than to embitter them'. ${ }^{31}$ The potential peace dividend was considerable: the enforcement of order and the defence of royal authority which would benefit the whole kingdom. Those responsible for upholding royal policy presented an optimistic view of what peace and royal justice could achieve. On the eve of the wars, in 1561, Louis de Bourbon, prince of Condé, wrote to the mayor and aldermen of Angers that, 'the means to remove the troubles, that religious diversity put amongst us, will give such good order everywhere, that good men will live in peace and repose'. ${ }^{32}$ Bernard Prevost, commissioner at Aix-en-Provence in 1566, nurtured the 'hope that equal distribution of justice without delving into things past will contain one another in peace and obedience'. ${ }^{33}$ Royal declarations presented a vision of the king as beneficent peacemaker which would be echoed by successive monarchs throughout the wars. The legislation issued in the wake of the Edict of 
Amboise, which restored peace in 1563, adopted a familiar, indeed familial, metaphor that the king as a good father towards his children wished to maintain peace between his subjects. ${ }^{34}$ In 1571, following the 1570 Edict of Saint-Germain, Charles IX declared his intention to carry out 'the honour and duty of a good king ... to establish so assuredly the repose of my subjects that they will never return to the calamities which they have suffered' ${ }^{35}$ However, royal policy sometimes appeared to be achieving the opposite of what it sought by exacerbating rather than defusing tensions. Nevertheless, following his alliance with the Catholic League in the Treaty of Nemours which effectively abolished the edicts of pacification in 1585, Henry III lamented its impact on his kingdom and his people. ${ }^{36}$

It was the king's hope that through the exercise of royal justice the pacification of France could be forcibly maintained. ${ }^{37}$ Increasingly, crown efforts were accompanied by those of special chambers attached to the parlements (the socalled chambres de l'édit) which were charged with enforcing the peace. Thus, in 1585, the chamber in Dauphiné requested guidance on how it could best assist the maintenance of the 'peace, union and repose' of the king's subjects in the province. ${ }^{38}$ Men of the law were among the strongest advocates of peace during the wars and were, furthermore, through the edicts, responsible for its implementation. In particular, they lauded peace's role in ensuring the proper functioning of the state and the maintenance of justice. Theirs was a neoplatonic utopian vision upheld by the virtuous government of the magistrate. ${ }^{39}$ The judge and royal commissioner, Ennemond de Rabot, in 1589 described 'the enjoyment of this great and invaluable benefit which is the gift of peace'; and, a decade later, in an address at Montélimar, hailed peace as 'a gift from God, mother of piety, foundation of justice' ${ }^{40}$ The theme of the judiciary and the law only being able to function properly during times of peace 
was echoed in contemporary literature as well as in speeches by judges. ${ }^{41}$ Jean Bodin $^{2}$ wrote that, 'It is not possible for religion, justice, charity, security of life, in short, all the liberal sciences and mechanical arts to flourish in any commonwealth which does not enjoy a profound and lasting peace. ${ }^{42}$ The court functionary, Pierre Habert, published his Treatise on the benefit and usefulness of peace, and the misfortunes produced by war in 1568, following the Edict of Longjumeau. He declared, with an Erasmian flourish, that peace was the source of all happiness, that religious difference was less important than national unity, and that all should obey the king and leave their consciences to the judgement of God. ${ }^{43}$ The assertion of the importance of public duty overriding private belief in the interests of a stable and peaceful kingdom was echoed in the neo-stoicism and scepticism in vogue among French scholars from the 1570s, of which Michel de Montaigne was a leading exponent. Montaigne rejected the dogmatism of extremists on both sides of the confessional divide because of the disruption they had caused to the country, and urged that all should submit to the monarchy as sole guarantor of civil order. ${ }^{44}$ Both Henry III and Henry IV embraced this school of thought, which shored up the preferred royal policy of conciliation of the faiths most notably in the 1590s and in support of the Edict of Nantes. Philosophical genres also influenced the poetry of the period. The use of commonplaces such as peace being the daughter or gift of God reveal that, likewise, judges and scholars drew on a rich literary heritage. ${ }^{45}$

James Hutton has identified peace poetry as a peculiarly French speciality from at least the fifteenth century, and this trend continued during the religious wars. $^{46}$ In particular, each edict of pacification was accompanied by a flurry of poetry and other literature of variable quality. By the mid-sixteenth century, the principal influences were the works of Erasmus and the poetry of Ronsard, culminating in his 
La Paix, Au Roy (1559). ${ }^{47}$ As a result of a strong existing tradition and reprints of earlier poems, the language of peace literature was full of general overtures about the virtues and benefits of peace, rather than specifics about recent events. Following the Edict of Amboise of 1563, Jean Passerat published his Hymne de la Paix, which referred to the need to establish a true peace, 'Not a feigned Peace, not an ensnared Peace, But a Peace which will last forever' ${ }^{48}$ The duration of the peace was an understandable fixation, accompanying its association with fertility and prosperity. Later lamenting the failure of earlier peaces promulgated in the month of March, associated with Mars the god of war, Passerat had higher hopes of the 1570 Edict of Saint-Germain published in the more auspicious month of August. ${ }^{49}$ Whatever misgivings the people had regarding the royal edicts, poets greeted them with unalloyed joy. The 1568 Hymne sur le Triomphe de la Paix refers repeatedly to 'happy’ as well as 'gentle’ and ‘noble’ peace; likewise, Guillaume du Bartas celebrated the 1580 Peace of Fleix in unequivocal terms, 'Oh Peace, happy peace, you are welcome'. ${ }^{50}$ These positive poetic themes re-emerged following the edicts of Nantes (and Vervins) in 1598.

Whilst peace was promoted by jurists and poets, the usual platitudes regarding the worst kinds of war being a civil war or a war fought over religion acquired a particular resonance. As lawyer and historian Estienne Pasquier put it in 1570, in civil wars victories are defeats, and neither Christianity nor royal authority are advanced by the sword and a general bloodletting. ${ }^{51}$ Furthermore, in a letter of 1585, he asserted that he 'would always prefer a tyranny during a peace than to be at the mercy of a civil war' ${ }^{52}$ In his will, the former chancellor and chief architect of the conciliation policy Michel de L'Hospital stated that 'there is nothing so dangerous for a country than civil war, nor more profitable than peace'. ${ }^{53}$ A placard posted up in 
Paris in 1577, recorded in the journal of Pierre de L'Estoile, stated that 'Peace strengthens a state, foreign war weakens it, civil war ruins it completely' ${ }^{54}$ Internal peace was the means by which the integrity of the realm was to be maintained, as Jacques de Silly, lord of Rochefort, put it in 1561: 'Peace and public tranquillity are the strongest walls in the world'. ${ }^{55}$ Similarly, the anonymous Apologie de la Paix of 1585 asserted that 'peace is the true cement to join together and strengthen the members of the commonwealth with its head, to construct the body politic' ${ }^{56}$ National unity also enabled resistance to foreign aggression, as in 1563, when the faiths were called upon to join together to expel the English from Le Havre, whilst calls for a universal peace in the 1590s were focused on the need to counter the power of Spain. ${ }^{57}$

Despite the apparent continuities in much of the traditional rhetoric, they conceal a variety of reactions to the negotiation of peace at various stages of the wars. The Edict of Amboise of 1563, the first edict of pacification, and the Edict of Nantes of 1598, which promised an end to the conflict, were able to be enforced relatively rigorously by the crown and its officials despite considerable opposition. However, the edicts which intervened, and the switches in royal policy which they reflected, were viewed on all sides with a mixture of resignation and suspicion, scepticism and hostility, due partly to the failure of preceding efforts at peace as well as to the changing balance of power between factions. Nevertheless, however much they disliked the edicts, and no-one was totally satisfied either with their terms or their implementation, the stance and arguments of all parties were determined by these acts of royal legislation. Most of all, Huguenot and Catholic interests vied to present the most persuasive and definitive interpretation of the impact of each peace for the kingdom and its people. 


\section{Confessional Voices}

The language used by both faiths to describe peace encompasses various contributions to a dynamic and sometimes bitter debate regarding the course of the wars and royal policy in particular. Although using similar terms and traditions, it reveals interpretations of peace which are often quite at variance with one another. The official peace established by the edicts of pacification during the wars was virulently contested; uncertainty and distrust was felt on both sides. Huguenot as well as Catholic opinion was divided over the benefits of a confessional peace; authors considered that it was in some way a betrayal of the truth, a concession to the validity of their opponents’ position. ${ }^{58}$ But it also promised a welcome respite in a bloody cycle of disorder and violence.

Unsurprisingly, the faiths were divided over the best means to resolve the troubles. Huguenots argued that only religious equality would achieve true peace between compatriots, 'equality (the) mother and wet-nurse of peace'. ${ }^{59}$ Pacification edicts offered recognition for the Protestant faith, but some were dissatisfied by the restrictions still placed upon them. The Brief discourse on the present state, and the means for remedying the troubles argued that three concessions would secure peace: religious freedom, public worship, and equal justice. ${ }^{60}$ The closest the Huguenots were to get to this ideal were the wide-ranging concessions of the 1576 Edict of Beaulieu; its short life reinforced Huguenot dissatisfaction and reflected the unacceptability of such a compromise to the Catholic majority. ${ }^{61}$ Many Catholics remained unconvinced that peace between the faiths in France, however circumscribed, was either possible or desirable. Militant Catholics believed that the most effective way for the king to fulfil his obligation as guardian of the public peace, to protect the Church and extirpate heresy as stated in his coronation oath, was to 
eliminate the Huguenots. However, there were many moderates who rejected both toleration and violence as a means to restore peace to the kingdom. Catholic writers upheld the belief that only religious unity could establish 'the peace of Christ, true peace, a peace free from enemies, a peace within which war is no longer hidden, a peace which does not crush us like adversaries, but joins us like friends’ ${ }^{62}$

Nevertheless, Catholic opinion was divided regarding which faith had most to gain from the peace edicts, despite their provision of rights to the Huguenot minority. Estienne Pasquier believed that the legislation had worked mostly in the Catholics’ favour, in particular, that of the king who had gained more over the Protestants by the edicts than by war. ${ }^{63}$ Militant Catholic voices indicated that the Huguenots could not be trusted either at times of war or peace; they benefited from perpetuating the conflict and during peace were able to reinforce themselves with men and money. ${ }^{64}$

Whatever its perceived advantages, in practice, neither faith embraced peace unconditionally. In particular, distinctions were to be drawn between 'good' and 'bad' peace. ${ }^{65}$ Huguenot acceptance was conditional on recognition of, and provision for, their faith. Whilst Philippe Duplessis-Mornay, advisor to Henry of Navarre, believed, like Erasmus and Pasquier, that 'there is no peace which is not worth more than the best war in the world'; equally, he stated in 1574 that 'We need a good and sincere peace not a covert war, friendship not ill-will, frankness not dissimulation, a lasting repose not a four-day truce'. ${ }^{66}$ La Noue, who in his memoirs discussed the virtues of peace directly in relation to the edicts of pacification, distinguished between true and false peace. He referred also to 'cut-throat' and to 'masked' peace, and that some disillusioned Huguenots had come to believe that 'there is always poison hidden beneath the beautiful lustre of this gold'. ${ }^{67}$ Protestant author Agrippa d'Aubigné, too, spoke of servile peace and that the dangers of peace were worse than those of war. ${ }^{68}$ 
In her lengthy correspondence with the Queen Mother, Catherine de Medici, during the negotiations of the 1570 edict, Jeanne d'Albret, queen of Navarre, referred frequently to the need and willingness to establish a 'good and secure peace', 'a happy and firm peace', after a ruinous and regrettable civil war. Like La Noue she was well aware of the shortcomings of a 'half-peace', a feeble or 'a faint peace', 'of building a peace of snow this winter which would melt when the summer comes'. ${ }^{69}$ Huguenot opinion was swayed by disappointment that the edicts had failed to bring them the longed-for benefits for which they had hoped. The short-lived Edict of Longjumeau of 1568 which ended the second war generated conflicting Huguenot responses. Whilst the poem, Hymne sur le triomphe de la Paix greeted the peace as a triumph over Catholic interests, most observers viewing it with hindsight were damning. ${ }^{70}$ La Noue thought it a 'nasty little peace', believing that the six months that it lasted were worse than a state of war for his coreligionists, in contrast to the contentment which accompanied the previous Edict of Amboise: 'concord, good conduct and obedience to the laws had already taken such a good course throughout France that she was totally repaired by it' ${ }^{71}$ To the Huguenot captain, Longjumeau was not worthy of the title of peace, but rather represented 'covert war' full of 'traps and snares'. ${ }^{72}$ Nevertheless, he thought that even a short peace was to be welcomed, as it would be beneficial as long as it lasted, as occurred with the two years instigated by the edict of 1570, such that 'few could complain about it'. ${ }^{73}$

Jean Du Tillet, Catholic clerk in the Paris parlement and one of the most virulent opponents of the policy of pacification, shared La Noue's distaste at the prospect of the 1568 peace, but for very different reasons. Although he was careful to praise Charles IX and his mother for their efforts to establish peace, he laid all the blame for its failure at the feet of the Huguenots who through their actions, he 
proclaimed, had revealed their treachery. In particular, Du Tillet saw no reason why the crown should feel obliged to treat with or keep faith with rebels and unbelievers, on the contrary God would oppose such a peace. ${ }^{74}$ Despite their protestations, the Huguenots had pursued an illicit war, and only God had the power to pardon them. The only means to make peace was for the Huguenots to repent, lay down their arms, and submit fully to the Catholic church and the king. Royal responsibility for ensuring that this was the outcome was clear, just as it would be interpreted as a sign of weakness if any concessions were made. Above all, it was necessary to avoid an 'iniquitous peace', an 'unjust and dishonest peace'. ${ }^{75}$ The tension between the king's role as peacemaker and his equally important martial prowess as a commander and defender of his people was exposed by such assertions. In particular, any peace which was less than honourable and advantageous suggested that the monarch was more fearful than feared. Clemency was a royal virtue, but only when it was accompanied by demonstrable power. If the king was soft on those who rebelled against him, how could he command the respect and loyalty of his subjects? The policies of Henry III and, more surprisingly perhaps, his successor, Henry IV, caused concern in this regard. ${ }^{76}$ In 1568, Jean Du Tillet argued that 'good Frenchmen' were disillusioned with peace and believed that Charles IX's present policy would lead to 'a truce followed by worse war, victory for your enemies, your surrender, their servitude and the total ruin of your said kingdom'. ${ }^{77}$ The only option, therefore, was to crush the Huguenots comprehensively, to exact their complete submission, so that there was no chance of their malice returning to challenge the well-being of France. Although many elements of his argument were traditional, Du Tillet's views were extreme. Nevertheless, they represent an influential strand of uncompromising Catholic 
invective which would become louder as the wars progressed, culminating in the pronouncements of the Catholic League.

As well as the views of writers like Du Tillet, radical Catholic opinion could draw on the polemic of preachers, such as Simon Vigor, who believed that toleration would incur God's wrath if it remained unopposed. ${ }^{78}$ Vigor described the 1570 edict of pacification as an 'edict of troubles'. ${ }^{99}$ The short-lived Edict of Beaulieu of 1576, which granted unparalleled concessions to the Huguenot minority, was condemned by Catholics as 'the poorest and most iniquitous peace ever', 'rather a preparation for and renewal than an appeasement of the troubles', and 'cause of more bitter wars and troubles than ever'. ${ }^{80}$ Even the Queen Mother was forced to recognise that 'this tolerance is very displeasing to God' and that it was necessary to sort out those areas 'neither at peace nor at war' ${ }^{81}$ For the Huguenot chronicler at Millau, in contrast, it was the outcome of the negotiations between Catherine de Medici and Henry of Navarre in October 1578 which was 'a treacherous peace, because it was a soporific' to his coreligionists in the south west after the disappointment of the failure of Beaulieu. $^{82}$ In particular, local circumstances and experience of confessional relations coloured communities' reactions to the terms of each peace. For the Catholic inhabitants of Lectoure in the Agenais, for example, the new treaty in 1580 would see them 'plunged into greater misfortune than ever and reduced to perpetual servitude to the enemy', for they were already living under the tyranny of garrison captains, and the previous peace had not brought them relief. ${ }^{83}$ The twists and turns of royal policy as the crown sought a resolution to the conflict resulted in a series of edicts which usually satisfied no-one and yet also opened up a dialogue between the crown, directly or through its officials, and local communities. 


\section{Crown and Communities}

The view of peace from the localities of France exposes above all the difficulties of its enforcement. Historically, peace has been regarded in different ways in accordance with its specific cultural context. Modern-day commentators on conflict resolution have identified the prerequisites for securing a meaningful peace which depend on the responsiveness of certain groups on each of the opposing sides. ${ }^{84}$ Despite its largely positive connotations, peace can generate anxiety among those who feel they might be disadvantaged by a truce in an unresolved dispute. Peace is more than simply the absence of war; it requires a process by which pacification can be maintained. Christian humanists, such as Erasmus, promoted peace as the natural, divinelyordained state of things, war as its corruption, but this was far from being a universally-held principle. ${ }^{85}$ Peace and war remain inseparable, often coexistent states, for as one contemporary commented, as 'after night comes day, (so) peace must follow war' ${ }^{86}$ Alongside the assertion of the principle of the 'just war', the favoured conclusion to the thorny issue of how war between Christians could be justified was when conflict was necessary to secure peace. In a speech to King Charles IX in 1568, at a time when the credibility of the royal policy of conciliation was under strain, Michel de L'Hospital cited the tirelessly repeated observation of Aristotle in his Politics that 'the aim of war is peace'. ${ }^{87}$ La Noue, whilst acknowledging lasting peace as the highest goal, recognised that war was sometimes necessary to secure it. ${ }^{88}$ The poet Vauquelin de La Fresnaye observed that the sole merit of war is to make us desire peace, just as hunger and thirst make food and drink taste better. ${ }^{89}$ However, whilst a just war might secure a good peace, an ill-conceived peace could nurture further conflict, as League supporter Pierre Matthieu asserted in 1588: 'Happy the combat which produces concord, Unhappy the peace which 
nourishes discord' ${ }^{90}$ More prosaically, peace was necessary to restore the royal finances so that the crown could afford to return afresh to war. ${ }^{91}$ At any rate, historians have argued that, during the religious wars, there was little distinction for much of the population of France between periods of open conflict and supposed peace. $^{92}$ Such overlap is also a commonplace of modern-day conflicts and complicates the efforts to resolve them.

Peacemaking in sixteenth-century France was just as tortuous as its modernday counterpart. Negotiating the peace is only the beginning; enforcement and acceptance take time. As Catherine de Medici put it in 1563 to the bishop of Rennes, ambassador to the Emperor, the establishment of peace is 'not the work of a day'. ${ }^{93}$ Violations of the peace were condemned by the crown and threats made against those who committed them. A stark warning was given by Pasquier in 1570 that whoever opposed the most recent edict would be 'blotted out ... banished and eaten by vermin, (and) sepulchred in the belly of a wolf'. ${ }^{94}$ No less threateningly, Catherine de Medici stated in a letter in 1563 that, 'my intention is to punish so rigorously those who want to upset this peace by their insolent behaviour, on either side, that it will be remembered and serve as an example to everyone of our desire to live in peace and to avoid any occasion to return whence we have just come'. ${ }^{95}$ Whilst the monarchy promoted the virtues of internal peace for the realm as a whole, and threatened with anathema any who opposed its will in this regard, there was no shortage of advice from local communities on how best to resolve disunity and to bring the civil strife to an end. The crown's was only one voice in an impassioned and ongoing debate. Its own officials were torn between the defence of Catholicism and their preference for order and harmony in society. Municipal authorities shared the obsession with maintaining order, but were enmeshed in local confessional disputes. The people, too, 
were concerned by the troubles which religious diversity had brought to their everyday lives. Above all, disillusionment grew as each successive peace failed to live up to the grand royal expectations with which it was heralded. Even the crown was forced to acknowledge that the 1563 Edict of Amboise had served, 'rather to revive between our subjects a new enmity, bitterness and rancour, than to conserve the peace and repose which we have striven to establish despite so many difficulties'. ${ }^{96}$ Ultimately, the rhetoric of peace would be undermined by the people's everyday experience of pacification within their localities.

Nevertheless, positive views of peace were also expressed by local communities: sometimes to deflect criticism or outside intervention, to express an ideal of order and tranquillity, or to oppose the king's promotion of coexistence. Thus, the municipal council at Marseille objected to the establishment of Reformed services in the town in 1562, because they would disrupt the 'good peace' maintained up to now. ${ }^{97}$ At Tours a similar appeal was made 'in the interests of peace', in 1570. ${ }^{98}$ In April 1563, the merchant draper of Troyes, Pierre Bel, stated that 'the king should uphold religion and the public peace', suggesting that he thought peace and toleration incompatible. ${ }^{99}$ Nevertheless, at Toulouse in the same year, the authorities thanked God for the peace and 'for better keeping the people in his obedience and restoring calm to the country'; a year later they were still 'well pacified'. ${ }^{100}$ So, too, the council at Lyon was able to report on what they had done in order to keep the people 'in peace and union under the king's obedience ... enjoying the benefits of the peace and tranquillity that by his edicts his majesty declares he wishes to be maintained in his lands'. ${ }^{101}$ In 1566, the crown remarked approvingly upon the 'happy repose’ of Provence, while Bordeaux was described as 'very peaceful'. ${ }^{102}$ Even amidst the fraught circumstances of the later wars and a series of short-lived and 
unsatisfactory edicts, such declarations continued. The desire of the Huguenots of Languedoc in 1575 for a 'holy and indissoluble pacification' may be unsurprising. ${ }^{103}$ So, too, that of the inhabitants of Bayonne close to the border with Spain in 1576, where the 'peace so much desired' had immediately reaped dividends with the easing of tensions. ${ }^{104}$ Yet even the fiercely Catholic Marseillais were able to 'rejoice in the edict of pacification' announced in $1580 .{ }^{105}$ Nevertheless, the establishment of a 'complete and solid pacification' in 1581 would prove problematic for the crown. ${ }^{106}$

Reports of peaceful coexistence, too, come predominantly from the period of the implementation of the Edict of Amboise. The faiths were called together to swear oaths to live in peace and union together at Bordeaux and at Blois, in July and October 1563 respectively. ${ }^{107}$ The language of brotherhood, friendship and unity characterised such declarations as, too, with the formal agreements by both confessions to uphold the edicts and live together in peace 'like brothers and friends', made at Poitiers and Grenoble. ${ }^{108}$ At Aurillac, in February 1564, both faiths informed the crown that they were living together peacefully and observing the king's edicts. ${ }^{109}$ Such assertions are more unusual, but do survive from, later in the wars. In the spring of 1568, reports of peaceful cohabitation were received from Laon and Soissons. ${ }^{110}$ In Lyon in May 1572, representatives of both faiths took an oath to live peacefully together in observation of the king's edicts. ${ }^{111}$ In 1578, in Agen, it was declared that obedience was maintained with the 'acceptance and contentment' of both religions. ${ }^{112}$ In many areas though, the imbalance between the faiths and confessional hostilities only became more entrenched as the conflict progressed.

Criticism by local communities of the edicts and their effectiveness in instituting peace are common. The Catholics of Mâcon in Burgundy declared to the king that, if he desired peace, his most recent edict would rather lead to a renewal of 
the troubles, 'new war and cruelty', as had happened with similar exercises in toleration heretofore. ${ }^{113}$ Accusations of violations of the peace by their adversaries was a primary weapon in the arsenal of those who opposed the policy of conciliation and believed that only religious unity could restore true peace. Few saw the situation as even-handedly as the royal commander in Poitou in March 1570: ‘There’s fault on both sides, if one puts one's hand on one's heart and tells the truth'. ${ }^{114}$ In appeals to the crown both sides emphasised that whilst they were peaceful, their opponents were not, thus forfeiting the benefits of peace. Behaving peacefully, on the other hand, entitled them to certain rights. Prior to the wars, in 1561, the mayor of Angers stated that, 'the king is seeking and trying all means to pacify and be rid of the troubles in his realm ... and we must follow his intention to keep the people living in peace, repose and tranquillity without any scandal, tumult or sedition according to his edicts'. ${ }^{115}$ But he then went on to say that local Huguenots were threatening to disrupt the peace by conducting services in the marketplace. For the authorities in Marseille, the best way to ensure peace was to incarcerate 'Huguenots and suspects' ${ }^{116}$ In Troyes, following the first war, concerns were expressed by several inhabitants about the disruption which Reformed services posed to 'the peace and tranquillity of the realm' and that the Huguenots 'have divided the people one against another and do not live in peace'. ${ }^{117}$ Similarly, the Catholics of Meulan near Paris informed the Queen Mother in November 1563 that they were 'peaceful and united', but their Huguenot neighbours were holding services in the suburbs 'which only cause division, disturbing the union and pacification which exists between the inhabitants'. ${ }^{118}$ In Dijon, the behaviour of the faiths was again contrasted, this time by the municipal authorities; Catholics were observing the edicts and peaceful, whilst the Huguenots, whom they had readmitted as required, were contravening the peace 
by committing acts of violence and sedition, threatening not only the welfare of the Church and the town but of the realm. ${ }^{119}$ Dijonnais certificates of abjuration referred to living 'catholiquement' as shorthand for peacefully and obediently. ${ }^{120}$ In contrast, in July 1569, the Huguenots of neighbouring Autun reported that they had 'always lived and wish hereafter to live in peace, union and concord with the citizens, neither attempting nor undertaking anything which is prohibited or forbidden', but that the local bishop’s legal action against them was intended 'more to ruin than to profit public peace and tranquillity’. ${ }^{121}$

Despite such claims to the contrary, the Huguenots' active pursuit of acts of war at a time of supposed peace in violation of the king's will was a repeated refrain. The sieur d'Escars concluded that the arming of the faiths in Bordeaux was 'rather the occasion for division than for peace'. ${ }^{122}$ From Nantes, in May 1568, the sieur de Bouillé remarked, 'I am often warned that they (the Huguenots) still want to restart the war'. ${ }^{123}$ The difficulty of securing even a brief respite in the seemingly continuous state of aggression in the southern provinces of the Huguenot crescent is particularly evident later in the wars. In 1574, lieutenant-general Jacques de Crussol reported to the king that, in Languedoc, the Huguenots were 'more at war than at peace', whilst in Poitou, according to the royal secretary Claude Pinart, they were opposed to 'the benefits of peace'. ${ }^{124}$ The parlement of Grenoble, at the end of January 1581, believed that the Huguenots of Dauphiné had no intention of obeying the most recent edict or of disarming, but on the contrary were carrying out 'acts of war'. Therefore, the court and local commanders did not think it an appropriate time to publish the peace. Huguenot hesitancy to lay down their arms and to trust in the efficacy of the edicts allowed Catholics to counter-accuse them of bad faith. Some six weeks after the Grenoble parlement’s declaration, the sieur de Hautefort reported 
that the Huguenot representative, Geoffrey de Calignon, had delivered an ample discourse on the 'means to achieve peace', or at least what preparations were necessary on the Catholic side, but that such declarations were insincere. By June, the lieutenant-general in the province, Laurent de Maugiron, underlined the divisions within the Huguenot camp: that whilst some were negotiating peace, others 'love only war ... pillaging and disadvantaging your godly intentions' and that their 'fine words' ('belles paroles') were delaying the army from taking charge. ${ }^{125}$

Huguenots, unsurprisingly, presented a different perspective on their attitudes to upholding the peace. In contrast to reports of Huguenot non-cooperation, the town of Montauban informed Blaise de Monluc in 1564 that local ministers were acting 'with all modesty and discretion', and both faiths were living peacefully together as before the troubles. ${ }^{126}$ Members of the 1565 Huguenot assembly at Ploërmel in Brittany (including the seigneurs d'Andelot and de Rohan) claimed that they were loyal subjects of the king and did not wish to disturb the peace nor contravene the edicts. ${ }^{127}$ In Lyon, the Reformed church declared that toleration was the answer to ensure that the faiths lived peacefully together; at Orléans, those of the religion advised that the provision of appropriate sites for services would 'keep everyone peaceful', and the deposition of arms would allow the inhabitants of the town to live in peace. ${ }^{128}$ Again, though, there is a contrast between the situation in the 1560 s and later in the wars. Tellingly, in 1583, Duplessis-Mornay wrote to Montaigne that if the Huguenots were left in peace, there would be no need for war. ${ }^{129}$ As the wars progressed, so Huguenot reluctance to accept the sincerity of royal overtures for peace grew, and Catholic patience with royal efforts to accommodate the Huguenots began to wear thin. As a result, the ability of the crown and its officials to enforce any settlement were severely restricted. 
By employing the conventional image of the king's obligation to pacify the realm, the French monarchy hoped to produce unity from division through the binding power of peace. However, like the edicts of pacification which embodied this royal commitment, the prospect of reconciling the faiths was conditional, temporary and uncertain. In the event, the linguistic and ideological plasticity of peace was wellsuited to a situation in which there were several different perspectives on the desirability and efficacy of negotiation and compromise in a dispute without resolution. Thus, the traditional rhetoric was used both to promote and to criticise the king's role as upholder of the peace and the protector of the realm, as well as to attack or defend the Huguenots as peace-breakers or peacemakers. Although the benefits of a kingdom at peace were universally accepted, coexistence as the best means to attain that end was frequently contested. Crown policy has traditionally been credited with bringing harmony to the discordant voices in 1598, yet that very same policy has been seen as divisive during the wars. In practice, in the provinces of France, local authorities struggled to restore order and to reduce tensions. Religious unity was viewed as essential to the national unity which the wars threatened to destroy, and each outbreak only confirmed many in this conviction. The rise of both Huguenot and Catholic militancy made confessional division more rather than less entrenched, and royal ability to prevent violations of the peace was limited. The accompanying debate encouraged discussion of how best to proceed in the interests of ending internal strife. However, the people became increasingly disillusioned that the monarchy could deliver on its promise of restoring harmony to a divided kingdom. The rhetoric of peace could not be translated into tangible and long-lasting benefits for both faiths in the communities of France, thus domestic peace remained fragile and contingent. 
${ }^{1}$ For example, B. Cottret, 1598, L'Édit de Nantes: Pour en finir avec les guerres de religion (Paris, 1997); J. Garrisson, L'Edit de Nantes: chroniques d'une paix attendue (Paris, 1998); P. Mironneau and I. Pébay-Clottes (eds), Paix des armes, paix des âmes (Paris, 2000); K. Cameron, M. Greengrass and P. Roberts (eds), The Adventure of Religious Pluralism in Early Modern France (Bern, 2000); T. Wanegffelen (ed.), De Michel de L'Hospital à l'Édit de Nantes: Politique et religion face aux Églises (Clermont-Ferrand, 2002). For a wider geographical and chronological perspective see O. Christin, La Paix de religion: l'autonomisation de la raison politique au XVIe siècle (Paris, 1997); J. Bossy, Peace in the Post-Reformation (Cambridge, 1998); T. Wanegffelen, L'Édit de Nantes: Une histoire européenne de la tolerance (XVIe-XXe siècle) (Paris, 1998); G. Chaix (ed.), Guerre et paix du moyen âge aux temps modernes: theories - pratiques - representations (Mainz, 2000).

${ }^{2}$ On the practical enforcement of the peace during the religious wars, see most recently J. Foa, 'Making Peace: The Commissions for Enforcing the Pacification Edicts in the Reign of Charles IX (1560-1574)', French History, 18 (2004), 256-74; and P. Roberts, 'Royal Authority and Justice during the French Religious Wars', Past and Present, 184 (2004), 3-32.

${ }^{3}$ D. Crouzet, La Nuit de la Saint-Barthélemy: un rêve perdu de la Renaissance (Paris, 1994).

${ }^{4}$ For example, X. Le Person, 'Practiques' et 'practiqueurs'. La vie politique à la fin du règne de Henri III (1584-1589) (Geneva, 2002); M. De Waele, 'Clémence royale et fidélités françaises à la fin des Guerres de Religion’, Historical Reflections/ Reflexions Historiques, 24 (1998), 231-52. 
${ }^{5}$ M. Turchetti, 'Religious Concord and Political Tolerance in Sixteenth- and Seventeenth-Century France', Sixteenth Century Journal, 22 (1991), 15-25.

${ }^{6}$ Foa, 'Making Peace', p. 257, states that 'Peace was but a word', but its meaning was highly contested.

${ }^{7}$ L. Racaut, Hatred in print. Catholic propaganda and Protestant identity during the French wars of religion (Aldershot, 2002), pp. 131-2, refers to the lack of dialogue between the faiths as 'competing narratives ... talking past each other'.

${ }^{8}$ J. Hutton, Themes of Peace in Renaissance Poetry (Ithaca and London, 1984), esp. pp. 27-31, 34-8, 49-55. D. Crouzet, 'Michel de L’Hospital et l'idée de la paix', in Chaix (ed.), Guerre et paix, pp. 103-18.

${ }^{9}$ Most notably during the Hundred Years War, see C.M.D. Crowder, 'Peace and Justice around 1400: A Sketch', in J.G. Rowe (ed.), Aspects of Late Medieval Government and Society (Toronto, 1986), pp. 53-81; A. Bossuat, 'The ReEstablishment of Peace in Society during the Reign of Charles VII', in P.S. Lewis (ed.), The Recovery of France in the Fifteenth Century (London, 1971), pp. 60-81. ${ }^{10}$ On sixteenth-century rituals of reconciliation, see most recently $\mathrm{X}$. Le Person, ‘A Moment of “Resverie”: Charles V and Francis I’s Encounter at Aigues-Mortes (July 1538)’, French History, 19 (2005), esp. 10-13. The kiss of peace, primarily a religious ritual, was received by both the king and queen of France at their coronations from the chief presiding cleric, see F. Cosandey, La Reine de France: symbole et pouvoir, XVe-XVIIIe siècle (Paris, 2000), p. 158. Notable examples of public embraces to indicate the end of enmity during the wars include members of the Houses of Guise and Châtillon in 1566, see R.J. Knecht, Catherine de’ Medici (London, 1998), p. 109; Henry III and the Duke of Guise in 1588, see Le Person, 'Practiques' et 'practiqueurs', pp. 535-47. On interconfessional gestures of 
reconciliation in the localities including oaths, see O. Christin, 'La coexistence confessionnelle, 1563-1567', Bulletin de la Société pour l'Histoire du Protestantisme Français (1995), 483-504, and notes 107-8 below.

${ }^{11}$ On the arrangement of this marriage by Catherine de Medici, as well as those of her other children, see Knecht, Catherine de’ Medici, pp. 138-41.

12 Le Person, 'A Moment of “Resverie”, 15-16, 24-5; N. Z. Davis, The Gift in Sixteenth-Century France (Oxford, 2000).

${ }^{13}$ For the iconography of peace during the wars, see Frances A. Yates, Astraea: The Imperial Theme in the Sixteenth Century (London and Boston, 1975), pp. 121-213; C. Desplat, ‘Henri IV “roi de paix”, dans l’historiographie d’Ancien Régime’, in Mironneau and Pébay-Clottes (eds), Paix des armes, p. 406. This was also expressed rhetorically see, for example, U. Langer, 'La rhétorique de la conciliation dans la Congratulation sur la paix générale, faicte au mois de Mars 1598... d’Étienne Pasquier', in Wanegffelen (ed.), De Michel de L'Hospital, p. 418.

${ }^{14}$ Le Person, 'A Moment of “Resverie”, 2, 26-7.

${ }^{15}$ Mémoires de Condé ou Recueil pour servir à l'Histoire de France (6 vols., Amsterdam, 1740), v, p. 49.

${ }^{16}$ Crowder, 'Peace and Justice’, p. 59. The avoidance of discord was a powerful weapon in the armoury of medieval monarchy, see R.I. Moore, 'Postscript: The Peace of God and the Social Revolution', in T. Head and R. Landes (eds), The Peace of God: Social Violence and Religious Response in France around the Year 1000 (Ithaca and London, 1992), p. 309; Bossuat, 'The Re-establishment of Peace’, pp. 60-81. ${ }^{17}$ Crouzet, Nuit de la Saint-Barthélemy, pp. 198, 253, 301.

${ }^{18}$ Hutton, Themes of Peace, pp. 151-3. 
${ }^{19}$ Notably in the anti-Spanish and anti-League Chant pastoral de quatre nourrissons des Muses (Paris, 1595), see Hutton, Themes of Peace, pp. 162-3.

${ }^{20}$ See A. Lebigre, La Justice du roi: La vie judiciaire dans l'ancienne France (1988), p. 225; Cottret , 1598, L'Édit de Nantes, p. 131; Crouzet, Nuit de la Saint-Barthélemy, p. 197.

${ }^{21}$ S. Daubresse, 'Charles IX et le Parlement de Paris: à propos de cinq discours du pouvoir’, Revue historique, 297 (1997), 450.

${ }^{22}$ For other allusions to the wars as afflictions in need of a cure, see M. Greengrass, 'Amnistie et oubliance: un discours politique autour des édits de pacification pendant les guerres de Religion', in Mironneau and Pébay-Clottes (eds), Paix des armes, pp. 116-18; Crouzet, Nuit de la Saint-Barthélemy, p. 261; Fragonard, 'Donner toute priorité’, pp. 425-6, 432-3.

${ }^{23}$ Crouzet, Nuit de la Saint-Barthélemy, pp. 259-60.

${ }^{24}$ Cottret , 1598, L'Édit de Nantes, p. 211.

${ }^{25}$ E. Powell, 'Arbitration and the Law in England in the Late Middle Ages', Transactions of the Royal Historical Society, 33 (1983), 55. See also S. Roberts, 'The Study of Dispute: Anthropological Perspectives’, in J. Bossy (ed.), Disputes and Settlements: Law and Human Relations in the West (Cambridge, 1983), pp. 7-16. ${ }^{26}$ On the assertion of this role by the nobility, see S. Carroll, 'The Peace in the Feud in Sixteenth- and Seventeenth-Century France', Past and Present, 178 (2003), 74115; by a parlement, S. Gal, 'Malaise et utopie parlementaires au temps de la Ligue: les “moyenneurs” du parlement de Dauphiné', Revue historique, 618 (2001), 403-31; and on other traditional mechanisms, see J-P. Barraqué, ‘Du bon usage du pacte: les passeries dans les Pyrénées occidentals à la fin du Moyen Âge’, Revue historique, 614 (2000), 307-35. 
${ }^{27}$ On the medieval tradition of the primacy of royal justice, Head and Landes (eds), The Peace of God, p. 8; A. Padoa-Schioppa (ed.), Legislation and Justice (Oxford, 1997), p. 357.

${ }^{28}$ Archives Municipales [hereafter AM] Aix, BB 59, 47v-50r (1 Aug. 1563).

${ }^{29}$ Daubresse, 'Charles IX et le Parlement', 450.

${ }^{30}$ F. de La Noue, Discours politiques et militaires, ed. F.E. Sutcliffe (Geneva, 1967), p. 784.

${ }^{31}$ Bibliothèque Nationale de France, Paris [hereafter BN], Fonds Dupuy, MS 322, fo. 147r (Mar. 1566).

${ }^{32}$ AM Angers, AA 3, 3 (13 July 1561).

${ }^{33} \mathrm{BN}$, manuscrits français [hereafter MS fr] 15882, fo. 54r (18 Oct. 1566).

${ }^{34}$ BN, Imprimés, F46827, nos. 33-4 (Nov. 1564). On this theme during the reign of the ultimate père du peuple, see N. Hochner, 'Louis XII and the Porcupine: Transformations of a Royal Emblem’, Renaissance Studies, 15 (2001), 17-36. Crowder, 'Peace and Justice', p. 56, also refers to 'motherhood' issues for authorities morally responsible for peace and justice.

${ }^{35}$ Daubresse, 'Charles IX et le Parlement', 450.

${ }^{36} \mathrm{P}$. de L’Estoile, Registre-journal du règne de Henri III, edited by M. Lazard and G. Shrenck (Geneva, 2001), vol. v (1585-1587), p. 33. See also Le Person, 'Practiques' et 'practiqueurs', p. 594.

${ }^{37}$ Roberts, 'Royal Authority and Justice’.

${ }^{38} \mathrm{BN}$, MS fr 15569, fo. 149r (2 May 1585).

${ }^{39}$ Gal, 'Malaise et utopie parlementaires', esp. 410; cf the neoplatonic vision of the king as peacemaker discussed in Crouzet, Nuit de la Saint-Barthélemy. 
${ }^{40}$ Gal, ibid., p. 428, harangue of 3 Nov. 1589; 1599 address quoted in E. Rabut, Le Roi, l'église et le temple: l'exécution de l'édit de Nantes en Dauphiné (Paris, 1987), p. 214.

${ }^{41}$ Hutton, Themes of Peace, pp. 113-16, 155; Jouanna, 'Idéologies de la guerre’.

42 J. Bodin, Six livres de la République (1576), Book 5, chap. 5 (transln by M.J.

Tooley (ed.), Six Books of the Commonwealth (Oxford, 1967), p. 167).

${ }^{43}$ Hutton, Themes of Peace, pp. 143-4.

${ }^{44}$ D. Quint, Montaigne and the Quality of Mercy: Ethical and Political Themes in the Essais (Princeton, N.J., 1998), esp. pp. ix-xv; P. Burke, Montaigne (Oxford, 1981), esp. pp. 1-2, 14-18, 28-35.

${ }^{45}$ See Hutton, Themes of Peace, pp. 141, 161; for peace as God's eldest daughter, F.G., Hymne sur le Triomphe de la Paix (n.p., 1568), and His only daughter, Matthieu, Stances sur la Publication de la Paix [A2].

${ }^{46}$ Hutton, Themes of Peace, p. 73.

${ }^{47}$ Hutton, Themes of Peace, pp. 106-8, 138-9. P. de Ronsard, Oeuvres complètes, ed. P. Laumonier (Paris, 1937), ix (1558-1559), pp. 101-16, written in celebration of the Treaty of Cateau Cambrésis.

${ }^{48}$ J. Passerat Troyen, Hymne de la Paix (Paris, 1563) [C]; also quoted in Hutton, Themes of Peace, pp. 141-2.

${ }^{49}$ Hutton, Themes of Peace, pp. 146-7.

${ }^{50}$ F.G., Hymne sur le Triomphe; G. du Bartas, Hymne de la Paix (Paris, 1582), quoted in G. Banderier, 'Henri IV et la paix: Du Bartas, D’Aubigné, Jeannin’, in Mironneau and Pébay-Clottes (eds), Paix des armes, p. 383; also in Hutton, Themes of Peace, p. 156. 
${ }^{51}$ E. Pasquier, Au Roy Congratulation de la Paix faite par sa Majesté entre ses subjectz l'unziesme jour d'Aoust 1570: the text is reproduced in V.E. Graham and W. McAllister Johnson (eds), The Paris Entries of Charles IX \& Elisabeth of Austria, 1571 (Toronto, 1974), pp. 247-63; also discussed in Hutton, Themes of Peace, pp. $149-50$.

${ }^{52}$ E. Pasquier, Lettres historiques pour les années 1556-1594, ed. D. Thickett (Geneva, 1966), p. 236.

${ }^{53}$ Quoted in M. Seong-Hak Kim, ““Nager entre deux eaux”. L’idéalisme juridique et la politique religieuse de Michel de L'Hospital', in Wanegffelen (ed.), De Michel de L'Hospital, p. 251.

${ }^{54}$ L’Estoile, Registre-journal, ii (1576-1578) (1996), p. 99.

${ }^{55}$ J. de Silly, seigneur de Rochefort, La Harangue de par la Noblesse de toute la France, au Roy tres-chrestien Charles neufiesme (Lyon, 1561), p. 26.

${ }^{56}$ Quoted in A. Jouanna, 'Idéologies de la guerre et ideologies de la paix en France dans la seconde moitié du XVIe siècle’, in M. Yardeni (ed.), Idéologie et propagande en France (Paris, 1987), p. 95. Hutton, Themes of Peace, pp. 32-3.

${ }^{57}$ On peace with Spain, see A. Boltanski, ‘Réconcilier les catholiques et l’État: Louis de Gonzague, duc de Nevers, et les dilemmes de la pacification du royaume à la fin du XVIe siècle’, in Mironneau and Pébay-Clottes (eds), Paix des armes, pp. 89-101.

${ }^{58}$ Fragonard, 'Donner toute priorité', pp. 436-8.

${ }^{59}$ H. de La Ferrière \& B. de Puchesse (eds) Lettres de Catherine de Médicis (10 vols., Paris, 1880-1909), vi (1897), p. 418 (4 Feb. 1579). Similar terms are used to describe religion and the love of God in La Harangue et remonstrance du peuple et tiers estat de France (n.p., 1561).

${ }^{60}$ Quoted in Mémoires de Condé, v, p. 130. 
${ }^{61}$ M. Greengrass, 'Pluralism and Equality: The Peace of Monsieur, May 1576’, in Cameron et al (eds), The Adventure of Religious Pluralism, pp. 45-63.

${ }^{62}$ G. de Assonleville, Atheomastix, sire adversus religionis hostes (Antwerp, 1598), quoted in Fragonard, 'Donner toute priorité', pp. 423-4.

${ }^{63}$ Pasquier, Lettres historiques, p. 237.

${ }^{64}$ Fragonard, 'Donner toute priorité', p. 430.

${ }^{65}$ On different sorts of peace see P. Contamine, 'Notes sur la paix en France pendant la guerre de cent ans/ L’Idée de guerre à la fin du moyen âge: aspects juridiques et éthiques’, in La France au XIVe et XVe siècles: Hommes, mentalités, guerre et paix (London, 1981).

${ }^{66}$ Quoted in H. Daussy, Les Huguenots et le Roi: le combat politique de Philippe Duplessis-Mornay (1572-1600) (Geneva, 2002), pp. 124-5.

${ }^{67}$ La Noue, Discours, pp. 784-5; cf Discours par dialogue sur l'Edict de la revocation de la paix (1569), which refers to the 'venomous snake hidden in this grass’, quoted in Crouzet, Nuit de la Saint-Barthélemy, p. 273.

${ }^{68}$ Fragonard, 'Donner toute priorité', p. 430.

${ }^{69}$ Lettres de Catherine de Médicis, iii (1887), pp. 346-52 (Feb. 1570). On the theme of seasonality, Passerat, in his Hymne de la Paix (1563), refers to peace inducing an all-year-round spring [A iii].

${ }^{70}$ Hutton, Themes of Peace, pp. 142-3; Crouzet, Nuit de la Saint-Barthélemy, p. 273.

${ }^{71}$ La Noue, Discours, p. 712 (and on Amboise, p. 783); Fragonard, 'Donner toute priorité', p. 425.

${ }^{72}$ La Noue, Discours, pp. 783-4, 787.

${ }^{73}$ Ibid., p. 784. 
${ }^{74}$ Escript touchant la paix des secondz troubles (1568), reproduced in E.A.R. Brown (ed.), Jean du Tillet and the French Wars of Religion: Five Tracts, 1562-1569

(Binghamton, New York, 1994), pp. 144-63.

${ }^{75}$ Escript touchant la paix, pp. 154-5, 162.

${ }^{76}$ On this aspect of these reigns, see A.M. Walker and E.H. Dickerman, 'The King Who Would be Man: Henri III, Gender Identity and the Murders at Blois, 1588', Historical Reflections/Reflexions Historiques, 24 (1998), 253-81; M. De Waele, 'Image de force, perception de faiblesse: La clémence d'Henri IV', Renaissance and Reformation/Renaissance et Réforme, 17 (1993), 51-60.

${ }^{77}$ Escript touchant la paix, p. 159.

${ }^{78}$ B. Diefendorf, 'Simon Vigor: A Radical Preacher in Sixteenth-Century Paris’, Sixteenth Century Journal, 18 (1987), 399-410.

${ }^{79}$ Ibid., 406.

${ }^{80}$ Quotations from Greengrass, 'Pluralism and Equality’, pp. 56, 61.

${ }^{81}$ Lettres de Catherine de Medici, v (1895), pp. 232, 236 (2 Jan. 1577).

82 J-L. Rigal (ed.), Documents sur la Réforme en Rouergue: Mémoires d'un calviniste de Millau (Rodez, 1911), p. 407.

${ }^{83}$ BN, MS fr 15564, fos. 87-9r (1581).

${ }^{84}$ R.L. Rothstein (ed.), After the Peace: Resistance and Reconciliation (London, 1999); B.B. Bunker and J.Z. Rubin (eds), Conflict, Cooperation and Justice (San Francisco, 1995); T. Gregor (ed.), A Natural History of Peace (London, 1996). ${ }^{85}$ Crouzet, ‘Michel de L’Hospital', p. 107; Hutton, Themes of Peace, p. 25. ${ }^{86}$ Quotation from Hymne de la Paix au Roy Tres-chrestien, in P. Matthieu, Stances sur la Publication de la Paix (Lyon, 1588) [B2]. D. Wolfthal (ed.), Peace and 
Negotiation: Strategies for Coexistence in the Middle Ages and the Renaissance (Turnhout, 2000), esp. pp. xvi-xvii; Desplat, ‘Henri IV “roi de paix”, pp. 405-25. ${ }^{87}$ M. de l'Hospital, Discours pour la majorité de Charles IX et trois autres discours, ed. R. Descimon (Paris, 1993), p. 32.

${ }^{88}$ La Noue, Discours, pp. 786-7.

${ }^{89}$ V. de la Fresnaye, Pour la Monarchie (Paris, 1570). This and La Noue are discussed in M-M. Fragonard, 'Donner toute priorité à la paix du Royaume: un argument des Politiques?', in Wanegffelen (ed.), De Michel de L'Hospital, pp. 426-7. In contrast, in his Six livres de la République, Book 5, chapter 5, Jean Bodin declared, 'how wrong are those who say that the sole end of war is peace' (Tooley (ed.), Six Books, p. 169).

90 Matthieu, Stances sur la Publication de la Paix [A3].

${ }^{91}$ Desplat, 'Henri IV “roi de paix”’, pp. 413-14.

${ }^{92}$ N.M. Sutherland, The French Secetaries of State in the Age of Catherine de Medici (London, 1962), p. 128; O. Christin, ‘Un Royaume en paix (1563-1567)? Tolérance, pacification et parité confessionnelle à Lyon’, in J. Fouilleron, G. Le Thiec \& H. Michel (eds), Sociétés et Idéologies des Temps Modernes: Hommage à Arlette Jouanna (Montpellier, 1996), p. 309.

${ }^{93}$ BN, MS fr 3181, fo. 52 (18 May 1563).

${ }^{94}$ Congratulation in Graham and McAllister Johnson (eds), The Paris Entries, p. 263 and n. 12, the classical allusion comes from Homer's Iliad. Hutton, Themes of Peace, pp. 149-50; on the cursing of the peacebreaker and the blessing of the peaceful as a Ronsardian conceit, see also pp. 151-3.

${ }^{95}$ Lettres de Catherine de Médicis, ii (1885), p. 7 (1 Apr. 1563). 
${ }^{96}$ BN, MS fr 4637, fo. 33r (14 Aug. 1565), Charles IX to his commissioners in Burgundy; cf BN, MS fr 17832, fo. 97v.

${ }^{97}$ Archives Communales [hereafter AC] Marseille, BB 40, fos. 177v-8, 180.

${ }^{98}$ BN, MS fr 15552, fo. 243r (25 Aug. 1570).

${ }^{99}$ AM Troyes, Fonds Boutiot, BB14, liasse 1, no. 24.

${ }^{100}$ AM Toulouse, BB 172 (1563); BB 173 (16 May 1564).

${ }^{101}$ AM Lyon, BB 83, fos. 74v-6 (Apr. 1563), also 132-3 (19 Aug.).

${ }^{102}$ BN, MS fr 15882, fos. 88 (21 Sept. 1566), 215-16r (12 July).

${ }^{103}$ BN, MS fr 15560, fo. 35 (23 Sept.).

${ }^{104}$ BN, MS fr 15560, fo. 79 (14 June 1576).

${ }^{105}$ BN, MS fr 15562, fo. 5r (4 Jan. 1580).

${ }^{106}$ BN, MS fr 15564, fos. 28-9r (7 Feb. 1581).

${ }^{107}$ BN, MS fr 15878, fo. 81r, D’Escars to Queen Mother (14 July 1563), 157v-9, report from Jean Pot (8 Oct. 1563).

${ }^{108}$ AC Poitiers, reg. 38, fos. 197-207 (25 May 1562); AM Grenoble, BB 19, fos. 1819 (10 Feb. 1564).

${ }^{109}$ BN, MS fr 18156, fo. 21v (Feb. 1564).

${ }^{110}$ BN, MS fr 15545, fos. 200-2 (Laon, 30 Apr.); 15546, fo. 28 (Soissons, 9 May).

${ }^{111}$ AM Lyon, BB 90, fos. 91v-2r (24 May 1572).

${ }^{112}$ BN, MS fr 15560, fo. 131r (25 July 1578).

113 AC Mâcon, GG 122, no. 30.

${ }^{114}$ BN, MS fr 15551, fo. 109r.

${ }^{115}$ AM Angers, BB29, fo. 36 (Nov. 1561).

${ }^{116}$ AC Marseille, BB 40, fo. 201r (1562). 
${ }^{117}$ AM Troyes, Fonds Boutiot, BB14, liasse 1, no. 24.

${ }^{118}$ BN, Collection du Vexin, MS 26 (4 Nov. 1563).

${ }^{119}$ AM Dijon, B 200, fos. 44-7 (1563).

${ }^{120}$ M.P. Holt, 'L’évolution des “Politiques” face aux Églises (1560-1598)’, in Wanegffelen (ed.), De Michel de L'Hospital, pp. 600-1.

${ }^{121}$ BN, MS fr 4048, fos. 44-5r, 48.

${ }^{122}$ BN, MS fr 15878, fo. 80v, D’Escars to Queen Mother (14 July 1563).

${ }^{123}$ BN, MS fr 15546, fo.25 (8 May 1568).

${ }^{124}$ BN, MS fr 15559, fos. 3r \& 67r (9 Jan. \& 4 May 1574)

${ }^{125}$ BN, MS fr 15564, fos. 20, 54 \& 143 (27 Jan., 15 Mar. \& 21 June 1581).

${ }^{126}$ BN, MS fr 15880, fos. 41-2 (22 Apr. 1564).

${ }^{127}$ BN, MS fr 15881, fo. 52 (20 Feb. 1565).

${ }^{128}$ Bibliothèque Municipale de Lyon, MS (Coste), 426; BN MS fr 3189, fo. 8.

${ }^{129}$ Daussy, Les Huguenots et le Roi, p. 218. 